\title{
Toplumsal Cinsiyet Olgusu ve Türkiye'de Kadınlık
}

\author{
Orhan BİNGÖL
}

Gümüşhane Üniversitesi Edebiyat Fakültesi Sosyoloji Bölümü

\begin{abstract}
Özet
Sosyal ilişkiler, sosyal sistemler ve genel olarak toplumsal yapı denilen bütünlük, içinde pek çok unsuru barındıran büyük bir ortaklıktır. Toplumsal yapı, göreli denge ve birliğinin yanı sıra çeşitli zıtlıklar, çatışmalar ve eşitsizlikleri de bünyesinde barındırır. Bunların en önemlilerinden biri toplumsal cinsiyet ayrımı ve ona dayalı haksız tanımlama, konumlandırma ve uygulamalardır. Bu anlamda biyolojik olarak kadın cinsine karşılık toplumsal olarak üretilen 'kadınlık' cinsiyeti, başlıca örnek olarak varlığını sürdürmektedir. Kadınlık, en yalın haliyle doğuştan ve doğal değil, sonradan ve yapay olarak oluşturulmuş cinsiyet ayrımının ismidir.

Toplumsal cinsiyet ayrımına neredeyse tüm dünya ülkelerinde rastlanabilir. Ayrım geçmiște de var olmuștur, bugün de devam etmektedir. Ancak yaşanma şiddeti ve göstergeleri toplumdan topluma farklılık göstermektedir. Türkiye, toplumsal cinsiyete dayalı ayrımda kadınlığın belirgin olarak yaşandığı ülkelerden biridir. Kadın, 'toplumsal cinsiyetinden ötürü' Türkiye'de var olan onlarca öteki içerisinde başı çekmektedir.

$\mathrm{Bu}$ inceleme genelinde teorik olarak toplumsal cinsiyetin kurguladığı kadınlık olgusu tanımlanacak, açıklanacak ve kadınlığın yaşadığı eşitsizlikler vurgulanacaktır. Bu doğrultuda ilkin biyolojik-toplumsal cinsiyet ayrımı ele alınacaktır. Ardından ayrımın belli başlı toplumlarda ne gibi uygulamalarla canlı kaldığı anlatılacaktır. Sonrasında genel tarihsel akış içerisinde Dünya'da ve Türkiye'de kadınlık meselesi toplumsal cinsiyet ayrımı bağlamında tartışılacaktır. Sonuç olarak Türkiye'de kadının genel durumu sergilenip yorumlanacaktır.
\end{abstract}

Anahtar Kelimeler: Toplumsal Cinsiyet, Kadınlık, Eşitsizlik, Türkiye

\section{The Fact of Gender and Womanhood in Turkey}

\begin{abstract}
Social relations, social systems and the overall integrity of the so-called social structure, containing many elements of a great partnership. Social structure, as well as a variety of relative stability and unity of opposites, incorporates the conflicts and inequalities. One of the most important of these are based on her gender discrimination and wrongful identification, positioning, and applications. In this sense, corresponds to the type of socially produced biologically female 'female' sex, exists mainly as an example. Femininity, most completely innate and natural, not artificially created, and subsequently

Gender discrimination can be found in virtually all countries of the world. Discrimination has existed in the past, continues to this day. Indicators and severity vary from society to society, but to happen. Turkey, one of the countries that experienced a significant gender-based discrimination womanhood. Woman, 'for social sex' in Turkey, the other dozens of existing lead.

Female gender as a theoretical speculations in the case of this study will be defined, explained and emphasized femininity inequalities experienced. Biological gender discrimination will be dealt with first in this direction. Live in societies that certain practices such as discrimination, then what will be discussed. Then, the flow in the general historical context of gender discrimination in the world and in Turkey will be discussed in a matter of femininity. As a result, the overall situation of women in Turkey exhibited and interpreted.
\end{abstract}

Keywords: Gender, Femininity, İnequality, Turkey

\section{Giriş}

Bütün toplumlar, tarihi akışta kendini kurmak, sağlamak ve devam ettirmek üzere yol almıştır. Bu güzergâh toplumun doğada hazır halde bulduklarının üzerine doğal olmayan, tamamı kültürel şeyleri eklemeleriyle biçim kazanır. Tarihsel süreçte toplumsal olarak üretilmiş sayısız üründen biri de toplumsal cinsiyettir. Toplumsal cinsiyet, biyolojinin kodladığı maddi bedenlere manevi anlamlar yükleyerek onları kültürel olarak tanımlamak ve ayırmaktır. Kadın ve erkeği, kadınlık ve erkeklik denen rol ve statüler bütünüyle özdeşleştirmektir. Bu ayrım, kadının aleyhine birçok eşitsizliğin doğmasında başrolü oynamaktadır.

Toplumsal cinsiyetin ürediği ve onlarca toplumsal cinsiyet uygulamasının türediği başlıca kaynak aile ve ataerkil gelenekler olmaktadır. $\mathrm{Bu}$ çalışmada toplumsal cinsiyete ataerkil aile, erkek egemen toplumsal düzen ve eşitsizlikler zeminlerinden yükselerek bakılmaktadır. Aynı doğrultuda kronolojik olarak Türk toplumları ve Türkiye'de toplumsal cinsiyetin, yarattığı kadınlık üzerinde nasıl hâkimiyet kurduğu güncel istatistiklerle somutlanmaktadır.

\section{Cinsiyet ve Toplumsal Cinsiyet}

İnsanın cinsiyeti, biyolojik ve toplumsal olarak pek çok noktada önemli işlevlere sahiptir. Erkek veya kadın doğmak ya da olmak nüfus dağılımında ve artımında dengeleri değiştirebileceği gibi cinsiyete dayalı toplumsal ayrım ve eşitsizlik konularında başrolü oynayan öğelerden biridir. Bireyin cinsiyeti biyolojik cinsiyet (sex) ve toplumsal cinsiyet (gender) olarak farklı hem de kökten farklı değerlendirilmektedir.

Biyolojik olarak "kadın ve erkek olmak, doğal ve doğuştan olarak adlandırılırken, kadınlık ve erkeklik ise toplumsallaşma süreci ile beraber kültürel bir yapılanmaya işaret etmektedir" (Hepşen, 2010: 14). Kadın-erkek ile kadınlık-erkeklik aynı şeyler değildir ve ayaklarını aynı yerlere basmaz. Buna göre insan, biyolojinin gözünde bir dişi 
ya da eril bedeniyle dünyaya gelir. Bedenin cinsiyeti, doğuştan gelen en doğal ve temel özelliklerden biridir. Bedenin ince ve zayıf mı yoksa kalın ve güçlü mü; doğurgan mı yahut doğurtan mı olacağı gibi ayrımlar bu biyolojik veriye göre temellenmektedir. Biyolojinin tanımladığı kadın ve erkek beden cinsiyeti aslında neredeyse yalnızca bundan ibarettir.

$\mathrm{Ne}$ var ki kimi biyolojist anlayıştakilere göre dişi-eril farklılığı, doğumdan sonraki tüm süreç için ana belirleyicidir. Mesela "cinsiyete dayalı işbölümü 'toplumsal olan' tarafından belirlenir ama biyoloji bu belirlenimin 'önkoşulu' ve temelidir" (Savran, 2009: 294). Bu bakımdan insanın cinsiyetini de kapsayan "doğa, hep daha toplumsaldır ama hiçbir zaman salt toplumsala dönüşmez... Nesnelerin doğal veya toplumsal öncesi nitelikleri, bu nesnelerle ilgili pratikler için kesinlikle önemlidir. Sözgelimi bir ağaca kahve ikram etmeyiz veya talaşla duvar boyamaya kalkmayız. Benzer biçimde, kromozomları itibariyle erkek olan birinden çocuk doğurmasını beklememeliyiz" (Savran, 2009: 296, 297-298). $\mathrm{Bu}$ türden örnekler çoğaltılabileceği ve bunlardan anlaşılacağı gibi biyolojik cinsiyet ayrılıkları önemsenmelidir. Aksi halde "eğer tartışılmakta olan insanların cinsiyeti göz ardı edilecek olursa, o zaman onların bedenli yaratıklar oldukları gerçeği de göz ardı edilmiş olur" (Wallace ve Wolf, 2004: 446). Ama bunlar insan cinsiyetinin doğal veya doğanın parçası olduğu, daha önemlisi daima doğal ve biyolojik kaldığı iddiaları için ne kadar yeterlidir?

Baştan biyolojik kabullerin karşısında yer alanlar için bir insanın dişil ve erilden çıkıp kadın ve erkeğe dönüşmesi biyolojiyle değil, tamamen toplumsal kültürel gelişmelerle ilgilidir. Toplumsal cinsiyet biyolojik ayrımdan çok daha öte ve geniştir. "Bireyin biyolojik cinsiyetinin doğrudan bir sonucu olmak zorunda değildir" (Giddens, 2012: 505). En net haliyle "toplumsal cinsiyet, bireyi kadınsı ya da erkeksi olarak karakterize eden psikososyal özelliklerdir" (Rice ve Kohl'dan akt; Hepşen, 2010: 13). Kadınsılık ya da kadınlık, erkeksilik veya erkeklik tümüyle toplumsal ve kültürel hadiselerdir. Birbirinden değişik zaman ve yerlere göre farklılık gösterebilmektedir. Herhangi bir coğrafyada yaşayan bir topluluk ya da toplumun kadın ve erkekten beklediği roller, diğerlerininkiyle birbirini tutmayabilir. $\mathrm{Bu}$, kültürün habercisidir. Birtakım teoriler, kimi kadınlık ve erkeklik eğilimlerinin ve davranışlarının evrensel dolayısıyla biyolojik olduğunu savunmaktadır. Örneğin cinsellik veya üreme konusunda kadın tek eşlilik, erkek çok eşlilik yönünde hep aynı doğrultuda hareket etme meylindedir. "Evrimsel psikolojiye göre bu durum iki cinsin doğası gereği normaldir ve olağandır. Evrimsel psikoloji erkeğin genetik olarak poligamik, kadının ise monogamik olduğunu söyler. Bu farklılığın sebebi kadının doğurganlığı ile erkeğin doğurtabilme özelliğinin ayrı olmasıdır" (Tarhan, 2005: 45). Ancak "mizaci bir davranışın evrensel olmasından hareketle köklerinin biyolojik olduğu sonucuna varılamaz" (Giddens, 2012: 506). Üstelik burada kadın ve erkeğin biyolojik ve bedensel farklılığı değil, toplumsal anlam ve kimlikleri tartışılmaktadır. Bu noktada "Delphy, erkeklerin ve kadınların toplumsal varoluş biçimlerinin, onların eril ve dişil varlıklar olarak bedenleriyle hiçbir bağlantısı olmadığını savunmaktadır... Biyolojik, anatomik olan, toplumsal eşitsizlik ve hiyerarşinin bir aracı olmaktan öte bir toplumsal anlam taşımamaktadır" (akt; Savran, 2009: 281).

Bireylerin cinsiyetinde biyolojinin mi toplumsalın mi daha baskın olduğu münakaşasında eşcinsellik çarpıcı bir örnektir. Eşcinsellik olgusunda toplumsal cinsiyet ayrımı ve yaptırımlarının, (özünde karşı çıkılan) biyolojik ayrımı kullanarak nasıl kemikleştiğine bakılabilir. Biyolojik cinsiyet ayrımı doğal ve öncel olarak 'üremeyi' kendine kıstas olarak seçmektedir. Fakat 'üremeye yönelik anatomik 'uyum', toplumsal cinsiyet kimliklerine atfedilen 'uygun' yönelimler biçimi altında heteroseksüelliğin doğallaştırılmasına yol açar... Her durumda kaçınılmazmışçasına, erkek eşcinsellere 'kadınsılık', lezbiyenlere 'erkeksilik' atfedilmesi bu doğallaştırmanın sonuçlarıdır” (Savran, 2009: 243). Başka türlü söylemek lazımsa eşcinsellik örneğinde işler, biyolojik bir kural olan iki farklı cinsten beden münasebetinin tersine işler. Aynı cinslerin birbirleriyle ilişkisi söz konusudur. Ama bu hal değiştirilmelidir. Değiştirme görevinde toplumsal cinsiyet devreye girmektedir. Toplumsal cinsiyetin öngördüğü 'kadın kadın gibi erkek erkek gibi olmalıdır' şeması eşcinsel bedenleri heteroseksüel (yaygın anlayışa göre normal) görünüş ve davranışlara uyarlamaya zorlamaktadır.

Uyarlama erkek ve kadın eşcinsellerin her ikisi için de geçerlidir. Şu var ki kadın eşcinseller, erkek eşcinsellere göre daha görmezden gelinen bir kategoridir. "Lezbiyenler tarih boyunca, erkek eşcinsellere göre daha az kovuşturulup daha az cezalandırıldıkları gibi, günümüzde de daha az 'araştırılmaktadırlar'... Tarih boyunca, lezbiyenlerle ilgili asıl kayg1, cinsellikleriyle ilgili olmaktan çok, erkeklerin 'toplumsal konumlarına', ayrıcalıklarına göz diktikleri düşünüldüğünde ortaya çıkmıştır. Erkek gibi giyinip erkek meselelerine girdiklerinde cezalandırılmıştır kadınlar ve/ya da lezbiyenler" (Savran, 2009: 250). Bu doğrudan ve alenen toplumsal cinsiyet ayrımcılığının işaretidir.

İnsanın cinsiyetini biyolojiden çok toplumsal kuralların belirlediğini ileri sürmek için başka bir örnek olarak transseksüeller gösterilmektedir. "Cinsiyetin sabit olduğu dogmasını yıkar transseksüeller çünkü kendilerini ne dişi ne eril olarak sınıflandırmaktadırlar. Böylelikle hem iki cinsiyetli düzeni sarsarlar hem toplumsal cinsiyetleri sonsuza kadar çoğullaştırırlar... Aslında birçok araştırmanın ortaya koyduğu şey bunun tam tersini işaret etmektedir... İddia edildiğinin tersine, toplumsal cinsiyetlerin sabitlenmesi ve fetişleşmesidir burada söz konusu olan. Cinsiyetler ötesine doğru atılmış bir adım gibi görünen bu değişim, aslında çoğu kez 'normal' bir erkek ya da kadın olmak için atılmış bir adımdır" (Savran, 2009: 324-325). Bu adımların başlangıcı ve varacağı yer toplumsal cinsiyet ayrımıdır. Toplumsalın öngördüğ̈̈ genelliklere, erkeği baskın tutmak üzere ikiye böldüğü hiyerarşiye dayalı ayrıştırmadır.

Toplumsal cinsiyet ayrımındaki en genel geçer göstergeler kadın olarak belirlenmiş cinse yönelik yaptırımlarla örneklenebilir. Tarihsel toplumsal olarak oluşturulmuş cinsiyet ayrımıyla kadın cinsine biçilen roller hep pasiflik, sakınma, korunma, savunma üzerinedir. Kadının yapması/olması gereken bu vaziyetler, erkeklerin meziyetlerine ve onların iktidarına karşıdır. "Butler, cinsiyetin maddeselliğinin onu inşa eden politikadan ve iktidardan ayrılamayacağını göstermek için tecavüz hakkında nasıl konuşulduğunu örnek verir... Bir kadının gece geç saatte tek başına sokakta dolaşmasının, tecavüze uğramanın 'peşinde koşmak' olarak sunulduğunu gösterir: Bir kadın o saatte ya evde kocasıyla oturuyor olmalıdır ya da ona sokakta el konacaktır. Ama şu ya da bu biçimde el konacaktır, çünkü onun 'cinsiyet/cinselliğii'nin sınırlarını 'el konmak' çizer"' (Savran, 2009: 269). 
Kadın cinsiyetinin/cinselliğinin çerçevelerini çizen, bedenine el koymayı uygun görebilen şey biyolojik olarak hücreler, DNA veya üreme organları değildir. Burada kadın bedeni üzerindeki sahipliğe hakkı olacağı düşünülen, erkek olarak tanımlanmış cinstir. Erkek(liğin) iktidarıdır. Erkeklik toplumda önemli ve geçerli bir statüdür. Erkeklik kadın üzerinden sağlanan ve erkek egemen toplum tarafından sağlamlaştırılan bir statüdür. Bir erkeğin erkekliğini ispatlaması ve koruması, erkekliğini kaybetme kaygısıyla daima gerilim taşımaktadır. Hal böyle olunca bu gerilimin kadın üzerindeki toplumsal cinsiyetçi yansımalarını görmek şaşırtıcı olmamaktadır (Kandiyoti, 1997: 75).

\section{Bazı Medeniyet ve Toplumlarda Genel Olarak Kadın}

Toplum denilen yapı, ilk oluşmaya başladığından bu yana çeşitli bölge ve vakitlerde birbirinden ayırt edicilik göstermiştir. Bununla birlikte toplumsal yapının bazı temelleri her bir zaman ve toplum için değişmez gibidir. Bu değişmezlerin başında aile gelir. Aile, bir bakıma kendisinin dev bir örüntüler zinciri olan toplumsal yapıya benzer şekilde bir bütünlükten meydana gelmektedir. Kadın, erkek, yaşlı, çocuk gibi öğelerin birlikteliği ve etkileşimiyle meydana gelen bir bütünlük. Kadını, oldu olası en çok da bu aile bütünlüğü içerisinde 'değerlendirme' eğilimi, ailenin varlığg gibi bin yıllardır devam etmiş bir gelenektir.

Toplumsal kültürel yapının gelişim ve değişim aşamaları içerisinde farklı yapısal özelliklerde birçok aile türü ortaya çıkmıştır. Bunlar arasında en geniş yeri ataerkil aile tutmaktadır. Ataerkil aileyle tek eşli ve ataya yani erkeğe dayanan aile, çok eşli yahut anaerkil aileye giderek üstün gelmiştir. $\mathrm{Bu}$ durum erkeğin ve özellikle de kadının konumunda radikal değişikliklere yol açmıştır. "Ailenin daha önceki biçimlerinde erkekler asla kadın sıkıntısı çekmedikleri, tersine istediklerinden de çok kadına sahip oldukları halde ilk karı-koca evliliğinin kurulmasıyla kadın, az bulunan, aranan bir şey haline gelmiş ve bundan ötürü kadınların kaçırılması ve satın alınmaları başlamıştır" (Altındal, 2004: 5). Bu gelişme, kadının 'aileyle anlam kazanmaya başlayan' sosyal pozisyonuna arka çıkarak kökleştirmiştir. Kadın, bundan böyle ilkin aile anası olarak kabul edilmeye başlanmıştır. Diğer bir ifadeyle "kadın, toplum tarafından artık her şeyden önce kocaya eş, çocuğa anne seçilmiştir ki bu sebeple ailenin bir ferdi olarak da öncelikle onun korunması gerekmektedir. Batı uygarlığında da Doğu uygarlığında da cinsel etiğin ilk amacı kadının namusuna sahip çıkmak olmuştur. Çünkü onsuz babalık belirsizleşeceği için ataerkil ailenin de varlığı tehlikeye girecektir” (Russell, 2003: 10). Neslin devamı, erkek otoritesinin değişmez garantisi olarak görülen aile, kadının biricik yeri ve yetki sınırları olarak karar kılınmıştır. Farklı bir dille artık "terazinin bir kefesine kadınların özgürlüğü, ötekine ailenin yıkılması konulmaktadı"” (Saim, 2004: 109).

Kadının direkt aile olgusuyla bir tutulması yeni ve nadir bir şey değildir. Birbirinden başka medeniyet ve toplumlarda kadın ile aile birliği ayrılmazlığı eskilerden bu yana önemli bir ikili olarak devam edegelmiştir. Örneğin "dünya uygarlık tarihinde Yunan medeniyetinin çok önemli bir yeri vardır. Yunan medeniyetinde kadının konumu neredeyse bugünkü dünyada çoğunlukla uygulanan kadın ve aile anlayışının temelini oluşturur. Yunanlılarda iyi bir kadının özellikleri şöyle belirtilmiştir: Sabırlı, zevkli, güzel, çocuklarına şefkatli bir anne, kocasına sadık bir eş ve ev yönetiminde başarılı bir idareci” (Doğdu, 2005: 54). Eski Yunan medeniyetine kısmen benzeyen fakat daha sert olan kadına yönelik bir başka anlayış ise tarihi Roma kültüründe görülmektedir. "Roma'da M.Ö. kadın, babasından kocasına aktarılan bir 'mal'dır. Yalnız başına ve yüzü açık olarak asla dışarı çıkamaz" (Doğdu, 2005: 5).

Yunan ve Roma kültür medeniyetlerini tarihi Avrupa toplumlarına genellemek doğru olmayabilecekse de, Hıristiyanlığın doğuşuyla Avrupa toplumlarında kadına dair birbirine çok yakın düşünüş ve uygulamalar doğmuştur. Bunlar aynı zamanda kadın-erkek hiyerarşisinin, çifte standartlarının da kök salmaya başladığı kabullerdir. Bu anlamda Russell'a göre "Hıristiyanlıkta evlilik dışı ilişkide bulunan kadının meşum (kötü) olduğu düşünülürdü ama başkasının karısıyla cinsel ilişkide bulunmadıkça erkek günahkâr sayılmazdı... Cinsel iffet üzerinde ısrarla duran Hıristiyan etiği kaçınılmaz olarak kadınların konumunu alçaltmakta büyük rol oynamıştır. Çünkü ahlakçılar hep erkek olduklarından kadınları baştan çıkartıcı olarak görmüşlerdir." (2003: 39, 49)

Kadının aile ve erkekten bağımsız düşünülmemesine dini kabuller de eklenince işin rengi gittikçe ve açıkça değişmeye başlamıştır. Açıktır çünkü dinin toplumsal yaşayışa tesirleri olağandır. Mevcut tesirler yalnızca Avrupa için geçerli değildir. Orta ve Uzak Doğu toplumlarında da kadına yaklaşımlar dinden beslenen kültürel yapıyla daha belirgin bir form kazanmaya başlamıştır. Örnekse "Hindistan'da sosyal yaşayış büyük ölçüde felsefi ve dini inanışlara göre şekillenmiştir. Toplum içerisinde kadının durumunun da bu inanışlara göre statü kazandığı söylenilebilir. Buna göre Hint dinlerinde kadın şu şekillerde tanımlanır: Manouizm: Kız; çocuk iken babasına, genç yaşta kocasına, dul halinde ise oğullarına bağlı kalmalıdır. Bir kadın hiçbir zaman bağımsız kalmaya çalışmamalıdır. Konfüçyanizm: Kadının hayattaki rolünü tek kelimeyle tarif etmek mümkündür: "İtaat". Budizm: Kadın, kötülüğün şahsiyet kazanmış şeklidir" (Doğdu, 2005: 58-59).

\section{Tarihi Süreçte Türklerde Toplumsal Cinsiyet ve Kadınlık}

Türk toplumunda var olan toplumsal cinsiyet ayrımını ve kadınlık olgusunu, toplumsal kültürel dokunun genel yapısıyla birlikte ele almak gerekir. Türk toplumunda kadını ayrıştıran toplumsal cinsiyetin varlığı, toplumun yüzyıllarca biriktirdiği, oluşturduğu ve temsil ettiği kimlikle birlikte okunarak anlamlı kılınabilir. Bu doğrultuda kadın, toplumsal cinsiyet ayrımına hem erkekler ve toplumun geneli tarafından maruz birakılmakta ve hem de aynı toplumdan müstakil olarak yaşamakta gibidir.

Türk toplumu birçok yönüyle kendine has bir toplumdur; içerisinde birbirine zıt pek çok parçacık barındırabilmektedir. Toplumun renkliliği, kimi zaman az bilen bazen çok yanılan yönleri, heyecanlılığı, hem Doğululuğu hem Batılılığı, bölgeler arasındaki uçurumları, çok kültürlülüğ̈̈u, kısmen reflekse benzer otomatik geleneksel tutuculuğu ya da tam tersi, olmadık derecede teslimiyetçiliği... Türk toplumunun taşıdığı tüm bu sıfatları bir arada düşünmek kolay değildir. $\mathrm{Bu}$ vasıfların neredeyse hepsi, ülke ve toplum genelinde farklı alanlarda yaşanan gelişmelerde belirgin etkilere sahiptir; dalgalanan ekonomide, ana rotası seçimlerle birlikte değişen politikada, hassas demokraside, sürekli değişikliklere gebe eğitim anlayışında, modelde yabancı uygulamada yerli sosyokültürel değer ve davranış kalıplarında... 
Ama Türk toplumu tüm bu niteliklerini, göz ardı edilemez büyük bir özelliğiyle frenlemektedir: Köklülük. Türkiye derin bir kültürel tarihe, yerli yabancı birçok unsurdan meydana gelen sosyal bir senteze sahiptir. Bu hem eski hem sürekli yenilenen toplumsal mozaik bazı yönleriyle sivrilmekte, bazı taraflarıyla törpülenmekte ve de gittikçe değişme göstermektedir. En sonunda Türkiye, bütün bu yaşanmışlıkları bir şekilde balansta tutabilmektedir. Türkiye'yi kendisi yapan, özgün kılan, içerisinde hayati duyarlılıktaki dozların bulunduğu (planlanmışa pek benzemeyen) bu balanstır denilebilir. Peki, bu toplumsal dengenin içerisinde toplumsal cinsiyet ayrımı ve kadınlık nerededir?

\section{1. İslamiyet Öncesinde Türklerde Kadın}

Tarihi süreçte Türk toplumu ve Türk kadını, İslamiyet öncesi, İslamiyet sonrası ve Cumhuriyet Türkiye'si olarak üç ana dönemde çalışılabilir. İlkin İslamiyet öncesine bakıldığında Türklerin sosyal hayatları, aile ve kadına yaklaşımları diğer zamanlara nazaran farklılık göstermektedir. İslamiyet öncesi dönemde Türklerde kadını hedef alan toplumsal cinsiyet ayrımı yok denecek kadar siliktir. "Kadın neredeyse erkekle eşit konumdadır. Ülke idaresinde Hakanla birlikte söz sahibidir. Evin idaresini kadın yürütür... Radloff'a göre erkeğin kadına dayak atması Türklerde duyulmamış bir olaydır... Çocuk eski Türklerde çok değerlidir. Kadının çocuğu olursa, ona olan sevgi ailede çok yükselir... Altaylarda kadın ve erkek arasındaki konuşma ve görüşme tamamıla serbesttir. Genç erkekler kız ve kadınlarla konuşurken, kadın yüzünü örtmeyi düşünmez" (Nirun, 1994: 23, 24). Buna göre kadın özel aile yaşamında, sosyal hayatta hatta siyasi platformda bile erkeğin gerisinde, toplumdan izole değildir. Hayatın içerisinde, erkekle birlikte ve toplum nezdinde görünür bir bireydir. İslam öncesi Türklerde toplumsal cinsiyet ayrımı genel ve büyük bir sorun olacak denli derinleşmemiştir.

\section{2. İslamiyet'in Kabulü ve Türk Kadını}

Türklerin İslam dinini kabul etmeleriyle, yaşamlarının her bir noktasında normal olarak önemli farklılıklar gözlenmiştir. İslamiyet'in Türklerin hayatına girmesi sadece bir din değişimi olmakla kalmamıştır. En az bunun kadar etkili olan Bizans-Arap-İran kültürü tesirleri zamanla Türk kültürü üzerinde belirgin izler bırakmıştır. Aynı zamanda Türk kadını için de değişiklikler kaçınılmaz olmuştur. İslamiyet'le birlikte erkekler ve toplum tarafindan amacından öteye yorumlanan dini yarg1, kural ve sosyal inançlarla kadının Türk dünyasındaki prestij ve statüsü başkalaşmıştır. "İslamiyet kadına aslında büyük haklar vermiş olmasına rağmen, bazı ayet ve hadislerin asıl manalarından farklı tefsirine uğratılması, İslam cemiyetini kadının tefsirlerinden mahrum etmiştir" (Altındal, 2004: 33). Örneğin Kuran'da kadının erkeğin yarısı kadar haklar statüsünde olduğunu gösteren iki hüküm vardır. Bunlardan birincisi iki kadın tanığın bir erkek tanığa eşit olacağı Bakara Suresi 282. ayettir. Diğeri ise miras hukukunda iki kadının bir erkeğe eşit tutulduğu Nisa Suresi 11. ayettir. Bu hükümlerin içerikleri ve gayeleri farklı bir takım şeyleri işaret edebilir. Kuran, özellikle indiği dönemin toplumsal koşulları düşünüldüğünde, kadının tıpkı bir eşyayı andıran hali hazırdaki durumu için çok büyük yenilikler getirmiştir. Ama içerisindeki bazı hükümler, kadına kıyasla daha güçlü olanlarca zamanla değişik noktalara kaydırılmıştır.
Benzer şekilde Türklerde, İslam ahlakının yanlış yorumlanmasıyla türetilmiş iki gelenek sosyal yaşamda kadının erkeği geriden takip etmesine sebebiyet vermiş olabilir. Bu geleneklerden biri kadının bir şekilde evde inzivaya çekilmesi, diğeri ise erkeğin birden fazla kadınla evliliğinin meşruiyetidir. Oysa Türklerin Arap ve İran kültürlerinden etkilenerek bu gibi uygulamalara gitmiş olduğu da bilinmektedir (Doğramac1, 1993: 16). Sonuçta İslamiyet'in birtakım uygulamalarla toplumsal cinsiyet ayrımını pekiştirdiği iddia edilmektedir. Esasında söz konusu uygulamalar yaşanma sıklıkları ve yolları değişmekle beraber İslamiyet'ten önce de hiç yok değildir. Fakat kadınla ilgili bazı İslami hükümlerin kutsal kitapta yer alması, meseleye meşruluk kazandırmakta ve aynı zamanda konuyu tartışmaya kapatmaktadır (Kandiyoti, 1997: 85).

İslamiyet'in etkileri ve Doğu'nun geleneksel kültürel nitelikleriyle birlikte Türk erkeği ve toplumunun kadına yaklaşımı, Osmanlılar dönemine varıncaya kadar kadını zor bir hayata yaklaştırır yönde ilerlemiştir. Osmanlı İmparatorluğu yönetimindeki Türk kadını üzerine yapılan değerlendirmelerin çoğunda araştırmacı ve tarihçilerin, İslamiyet ile Bizans etkilerinin ağırlığına neredeyse eşit mesafede yer verdikleri görülmektedir.

Osmanlı İmparatorluğu çatısında Türk kadını için işlerin daha güç ve katılaşmış olduğu söylenebilir. Doğramacı'ya göre "Osmanlılarda kabul gören İslam Medeni Kanunu'yla erkeğin otoritesi artık kesinleşmiş, kadının eşini seçme hatta onu görme hakk1 bile elinden alınmıştır" (2003: 17). Osmanlılarda kadını erkek himayesine ve de çok eşlilik kıskacına sokan uygulamalar dikkat çekmektedir. Altındal'a göre (2004: 34) "bilindiği üzere Osmanlılarda kadın denilince bütün dünyada herkesin aklına neredeyse ilkin harem gelir. Hâlbuki harem sanıldığı gibi ne Türk icadıdır ne de Osmanlının bir keşfidir. Osmanlılar harem olayını Bizans ve İran'dan almıştır. Bu özeniş zamanla sarayda ve çevresinde yayılmıştır. İşte poligami bu yolla tam olarak yaygınlaşmış ve kesinleşmiştir." Poligami, Osmanlı kadınının fazlasıyla mahrem ve üreme mercii olarak kabul edildiğini gösteren toplumsal cinsiyet anlayışının bariz örneklerinden biridir.

Osmanlının yıkılmadan önceki son 50-100 y1lı toplumun geneli için olduğu kadar Türk kadını açısından da manidardır. $\mathrm{Bu}$ dönemler Osmanlıda yenileşme, Batılılaşma, modernleşme hareketlerinin tırmandığı zamanlardır. $\mathrm{Bu}$ anlamda Tanzimat, kendinden sonraki kadın ve kadın modernleşmesiyle alakalı hızlı gelişmelere ön ayak olmuştur. "Tanzimat, memlekete pozitivizmi getirmiştir... Tanzimat Fermanı'nda kadınlar için yeni hükümler yoktur. Fakat Tanzimat'ın getirdiği yenilik zihniyeti bütün memleket işlerinde olduğu gibi kadınlara ait konularda da görülmüştür. Kızlar için ebelik öğretimi, kız rüştiyeleri (bir çeşit ortaokul) ilk defa 1858 'de, kız öğretmen okulları 1870'de açılmıştır. Terzilik, öğretmenlik, hemşirelik, eczacılık vb. meslek ve sanatlarda kadınlara yer verilmesi Meşrutiyet'ten (1908) sonra başlamıştır. 1909'da Halide Edip'in kurduğu Teali-i Nisvan-Kadınların Yükselmesi Derneği ile 1913'te Nuriye Ulviye tarafından kurulan Müdafaa-i Hukuk-u Nisvan-Kadın Haklarını Koruma Derneği dikkat çekicidir. 1923 yılında ise hukuk ve tıp fakültelerine kız öğrenciler alınmaya başlanmıştır” (Nirun, 1994: 320 - 321).

\subsection{Türkiye Cumhuriyeti ve Cumhuriyetin Yeni Kadını}

Osmanlı İmparatorluğu'nun ardından cumhuriyetle 
birlikte Türkler, toplumun tamamını muhatap alan köklü yeniliklerle karşılaşmıştır. Mustafa Kemal Atatürk'le, Türk siyasi ve toplumsal yapısı ve aynı zamanda Türk kadınının geleceği ilerici ve çarpıcı olarak değişikliğe uğramıştır. TC Başbakanlık Toplumsal Cinsiyet Eşitliği Ulusal Eylem Planı'na göre “Türkiye'de toplumsal cinsiyet eşitliği politikalarının zeminini Cumhuriyet devrimleri oluşturmaktadır... Bu reformların temelinde ise kadınların kamusal alana girmeleri ve erkeklerle birlikte kalkınma sürecine katılmaları yer almaktadır" (2008: 13). 1926 yılında Türk Medeni Kanunu'yla kadına temel haklar verilmiş, tek eşlilik kabul edilmiş, mülk edinmede kadın da hak sahibi olmuştur. Cumhuriyetle birlikte Türk kadınına eğitim kapıları sonuna kadar açılmaya çalışılmıştır. Tevhid-i Tedrisat kanunu ile Türk kadınına 1926 yılından itibaren harp okulları dışında tüm eğitim kurumlarına girme hakkı tanınmıştır. Türk kadını seçme ve seçilme hakkına 1934 yılında kavuşmuştur. İtalya ve Fransa'da kadınların bu hakları ancak 1940-1950 arasında, İsviçre'de ise 1970 tarihinde kazandığı unutulmamalıdır.

Türkiye Cumhuriyeti'nin kurulması, Türk dünyasının modernleşme girişimlerinde zirve noktası olarak alınabilir. Türk modernleşmesi başlı başına incelenecek denli geniş ve ayrı bir olgudur. Bu çalışmanın sınırları dışına taşacak bir konudur. Burada, Türkiye Cumhuriyeti'nin kuruluşundan itibaren Türk toplumunu ve kadınını Batılı, laik, modern bir doğrultuda yönlendirmeyi amaçladığını söylemekle yetinilebilir. Cumhuriyetin amaçları çeşitli önemli inkılâplarla, yasal ve anayasal düzenlemelerle hayata geçirilmeye çalışılmıştır. Bu süreçte kadına karşı pozitif ayrımcılığın kollandığı açıktır. Kaldı ki kadın, modern Türkiye Cumhuriyeti'nin özellikle ilk dönemlerinde başlıca çalışma ve tartışma alanlarındandı. Öncü için "Türkiye Cumhuriyeti'nin yeni kadını rejimin simgeleştirilmesinde ön planda rol aldı: Törenlerde şortla gösteri yapt1, okul ya da asker üniformasıyla bayrak taşıdı ya da balolarda Batı modasina uygun gece elbisesiyle dans etti. Atatürk'ün erkek çocukların tercih edildiği ataerkil bir toplumda k1z çocuklarını evlat edinmesi de bu bağlamda anlamlı bir olgudur" (akt; Kandiyoti, 1997: 175).

Ancak Türkiye'de tarihi bir geçmiş olmadan, toplumsal bir hazırlık ve hazmetme dolgusu bulunmadan yapilan girişimler beyhude olmamakla birlikte daha ziyade üst sınıf kadınlarınca kabul ve uygulama görmüştür. Cumhuriyetle birlikte başlatılan ve zamanın koşullarına göre uygulanan toplumsal cinsiyet eşitsizliğini yok etme hedefli tüm iyileştirmeler yavaş ve sorunlu bir yayılım göstermiştir. Bu anlamda Türk kadını birçok ikilikten en azından yasal olarak 'kurtulmuş' ve fakat toplumsal bağlamda tam ve gerçek olarak ‘özgürleşememiş’tir” (Kandiyoti, 1997: 72). Türkiye'ye ait son yılları yansıtan istatistikî bilgiler bunu desteklemektedir.

\subsection{Güncel Verilerle Türk Kadını}

Bugünkü Türkiye'de kadın, toplumsal cinsiyet belirlenimciliğinden hareketle birçok alanda erkekler ve toplum geneli ile bir asimetri yaşamaktadır. Kadın bu orantısızlığa, en başta cinsiyetinin gerektirdiği bağlamda eğitilmesi, sosyalizasyonu ve yaşamasından ötürü maruz kalmaktadır. Kadının toplumsal hayatta karşılaştı̆̆ eşitsizlikler, başka yan değişkenleri içermekle birlikte tek bir kökten 'toplumsal cinsiyet ayrımından/kadınlık olgusundan' temel almaktadır.

Toplumsal cinsiyet ayrımı tabanında, Türkiye'de önce kadının çalışma durumu ele alınabilir. Dünyada kadınların işgücüne katılım oranlarına bakıldığında 2011 yılında Türkiye'nin \% 29 ile dünyada en düşük katılım oranına sahip olan ülkelerden biri olduğu görülmektedir (OKA, 2013: 62). Günümüzde geleneksel Türk aile yapısı ve erkeği, kadın için, başta çalışma ve eğitim hayatı olmak üzere pek çok konuda söz sahibidir. 2012 yılı istatistiklerine göre Türkiye'de kadınların medeni durumlarına bakıldığında en yüksek pay \% 63.9 ile evlilerde iken en düşük oranı \% 3.5 ile boşanmış kadınlar temsil etmektedir (OKA, 2013: 23). Türkiye'de boşanma oranları eski yıllara nazaran artış gösteriyorsa da evlilik, Türk kadını ve erkeği için yüksek önem taşımaktadır.

2009 yılında elde edilenlere göre kadının ortalama ilk evlenme yaşı 23 ve annelik yaşı 27 , erkeğin evlenme yaşı 26,3'tür (TÜİK, 2010: 26). Türk kadını aslında Türk erkeği gibi görece çok genç yaşta evlenmektedir. Evlilik, erkek için aile hayatının haricindeki yaşamda büyük bir engel teşkil etmemektedir. 2010 verilerinden hareketle Türkiye'de erkek işgücüne katılma oranı \% 70.8, kadın işgücüne katılma oranı ise \% 27.5'tir (TÜİK, 2010: 48). Kadının işgücüne katılma oranını düşüren çeşitli sebeplerin başında evlilik gelmektedir. 2012 istatistiklerine göre Türkiye'de kadın nüfusunun \% 58.9'u ev işleri ile meşguldür. \% 2.4 ise ailevi nedenlerle çalışmamaktadır (OKA, 2012: 84). Kadın, evliliği nedeniyle aktif çalışma yaşamına entegre olmakta zorlanmaktadır. 2010'da tespit edildiği haliyle istihdam edilen kadınlar içerisinde medeni durumuna göre en az oran, eşi ölenler (8.5) ile evli kadınlara (24.2) aittir. Destekler biçimde yine 2010 istatistikleri kadın nüfus içinde işgücüne dâhil olmama sebepleri arasındaki en yüksek pay olarak evliliği işaret etmektedir (TÜİK, 2010: 59, 64).

İçinde bulunduğumuz çağ razı olunsun olunmasın çalışma, üretme, faal olma ve aynı zamanda tüketme çağıdır. Bugünkü dünyada hayat evde değil, dışarıdadır. Bürolarda, eğitim binalarında, fabrikalarda, hizmet birimlerinde, iletişim, teknoloji ve kültür merkezlerindedir. Oysa "değeri paranın belirlediği çağdaş toplumlarda ev kadınları para ekonomisinin dışında çalışan bir gruptur. Onların yaptıkları iş para karşılığı değildir, dolayısıyla değersizdir, dolayısıyla gerçek bile değildir" (Saim, 2004: 215). Gerçek olan, toplumsal cinsiyet ayrımının en bilindik göstergesi olarak kadını ana olarak tanımlamaya devam etmektir. Öbür türlü söylenirse "kadınların rollerini (geçmişte olduğu gibi bugün de) doğurganlıklarına bağlama ya da onları bunalım dönemlerinde işe en son alınan ve işten ilk çıkarılan bir 'yedek emek gücü'ne indirgemeyi amaçlayan bir dizi uygulamayı haklı çıkarmak için 'ev kadınlığı ideolojisine' ve 'kadınlara araçsal bakış açısına' hâlâ yaslanılmaktadır', (Michel: ty.: 98).

Evlilik ve aile yaşamı, toplumun bekası için şüphesiz kaçınılmazdır. Bunu tartışmanın bir karşılığı yoktur. Fakat Türk aile yapısı biçim olarak gittikçe çekirdek aileye doğru küçülüyorsa da yapı bakımından işlevlerini yitirmiş gelenekselliğini ve ataerkilliğini koruyor gibi durmaktadır. Kadın, erkeğin hükümlerinden ve önceliğinden çıkıp henüz onunla aynı konuma yükselememiştir. Kendine 'aile kadını'ndan başka sıfatlar edinmekte zorlanmakta, edinse dahi rol çatışmalarına gebe kalabilmektedir. Aslına bakılırsa bu ataerkil işleyişte yeni kuşakları yetiştirme görevindeki kadının kendisinin bizzat rolü yok değildir. Geleneksel ataerkil aile içine doğup onunla büyüyen kadın yine aynı ataerkil kaideleri sürdürme eğilimindedir. Örneğin geleneksel Türk ailesinde "erkek çocuk doğurmak ve hanede kıdem 
kazanmak güç dengesini kadın lehine değiştirse de, kadın, gücün doruğuna kaynana olarak ulaşır... Anne oğul ilişkisi hayati önem taşır ve anne gelecekteki güvencesi olarak gördüğü oğlunu kayırır; böylece genç erkeğin kendi eşinden hizmet beklentilerini şekillendirir. Gelin kaynana çekişmesi olarak ortaya çıkan olgu ataerkil kalıbın bir ürünüdür" (Kandiyoti, 1997: 79).

Kadının çalışma durumunu yansıtan sayılar yalnızca iş hayatı için anlam taşımamaktadır. Türkiye'de kadına şiddet ve kadının mutluluk düzeyi ölçümleri kendi içerisinde ikilemler barındırmaktadır. Örneğin 2012 kayıtlarına göre Türkiye'de her 100 kadından en az 36'sı eşi veya birlikte olduğu kişi ve kişilerden şiddet görmüştür/görmektedir (OKA, 2012: 86). Buna rağmen 2010 yılında yapılan araştırmalara göre her 100 kadından 70.5 'i evliliklerinden memnundur. Türkiye'de kadınların mutluluk düzeyine bakılırsa \% 53'ü mutlu, \% 7.6's1 mutsuzdur. Kadınların mutluluk kaynağı kişiler sorulduğunda ise alınan yanıtlara göre bu kişilerin \% 65.9'u tüm aile, \% 19.3'ü çocuklar ve ancak \% 1.6'sı kendidir (TÜİK, 2010: 74, 76, 80). Buradaki sayılar esasında kadınların içinde bulunduğu yanlış bilinç, birey olamama ve toplumsal cinsiyeti benimsemişliğin satır araları olarak okunabilir.

Türkiye'de ev dışında çalışan kadınların sektörel dağılımına bakıldığında, kadın çalışanların toplum geneli ile paralellik taşımadığı görülmektedir. 2012 verilerinden yola çıkıldığında Türkiye'de tarımın istihdamdaki toplam payı \% 25.5 olup kadınlar için bu oran $\% 42.2$ ye çıkmaktadır. Kadın nüfusun diğer \% 42.6's hizmetlerde ve kalan \% 15.2'si ise sanayi sektöründe çalışmaktadır (OKA, 2012: 84). Yüzde olarak bu oran ABD, Belçika, Norveç ve İspanya'da ise 1'dir. Geri kalan k1sım \% 90'lar ile önce hizmetlere sonra sanayiye dağılmaktadır (OKA, 2013: 47). Ek olarak 2011'de tespit edilen oranlara göre Türkiye'de kadınların \% 58'inin sosyal güvenlik kurumuna kayıtlı olmadan çalıştığı belirtilmelidir (OKA, 2013: 52).

Türkiye'de çalışan kadınların yaklaşık yarısı tarım sektöründe yer almaktadır. Kırsal yerleşim birimlerinde bu oran normal kabul edilebilir. Ancak kadınların işgücüne katılma oranları kentsel alanlarda daha da düşüktür. Kırdan kente göç ile kentsel alanda piyasanın gerektirdiği niteliklere sahip olamayan kadın, işgücünün dışına çıkmaktadır.(OKA, 2012: 84) Bunun anlamı, kadın işgücünün yüksek vasıf ve nitelik gerektirmeyen işlerde yoğunlaşmışlığıdır. Bu sonuç ilk olarak kadının eğitim durumuyla alakalıdır.

2009'da tespit edildiği haliyle 6 ve üzeri yaş grubunda Türkiye'de okuma yazma bilmeyen kadın nüfusu 12.1 erkek nüfusu ise 3.0'dır. 15 ve üzeri yaş grubunda Türkiye'de okuma yazma bilmeyen kadın nüfusu 14.7 erkek nüfusu ise 3.6 iken, 25 ve üzeri yaş grubunda ise Türkiye' de yüksekokul ve fakülte mezunu kadın nüfusu 7.3 erkek nüfusu ise 11.2' dir (TÜİK, 2010: 11). Kadın ve erkek nüfusun eğitim görmüşlük oranlarında okuma yazma seviyesinden yüksekokul ve fakülteye kadar her aşamada eşitsizlik söz konusudur. Diğer bir söylemle Türkiye'de eğitim görmüşlüğü yansıtan veriler, hangi yaş grubunda olursa olsun erkeklere nispeten kadınlarda daha düşüktür. Türkiye'de kadınların eğitim durumlarıyla bağlantılı bir başka gerçek, her kadının eğitim alma imkânına sahip olamadığıdır. "Günümüzdeki bütün çalışmalar üniversite öğrencisi kızların sosyoekonomik statülerinin toplam erkek öğrenci nüfusununkinden yüksek olduğunu göstermektedir; bu durum kadınlar arasında seçkin yetiştirme örüntüsünün devamlılığının bir göstergesidir"
(Kandiyoti, 1997: 71).

Eğitimle ilgili akademik veriler incelendiğinde ikilik değişmemektedir. 2009-2010 yılları kayıtlarında akademik unvanlarına göre kadın ve erkek akademisyenlerin birbirlerine kıyasları şöyledir: Türkiye'de 4.038 kadın profesöre karşılık 10.533 erkek profesör bulunmaktadır. Bu sayı kadın doçentlerde 2.494 erkek doçentlerde ise 5.333'tür. Kadın yardımcı doçentler 6.992, erkek yardımcı doçentler ise 12.791'dir (TÜİK, 2010: 46). Burada eklenmeli ki kadın ve üniversite, kadın merkezli çalışmalardan mahrum değildir. TC Toplumsal Cinsiyet Eşitliği Ulusal Eylem Planı'na göre Türkiye'de 15 üniversitede farklı disiplinlerden akademisyenlerin yer aldığı ve toplumsal cinsiyet, kadının sosyal ve ekonomik statüsü, sağlık, eğitim, şiddet gibi konularda araştırmalar yapan Kadın Sorunları Araştırma ve Uygulama Merkezleri bulunmaktadır. Ayrıca 4 üniversitede Kadın Çalışmaları Ana Bilim Dalı bulunmaktadır (2008: 23).

Türk kadınının toplum genelinde profesyonel olarak ne derece fikir veya söz sahibi olduğunu gösterebilecek son bir istatistik kadın ve siyaset bağlamında paylaşılabilir. 2007 seçim yılına göre kadın milletvekili sayısı 50, bakan sayısı 1 'dir. Bu yıllarda 500 erkek milletvekiline paralel 23 erkek bakan bulunmaktadır (TÜİK, 2010: 72). Ayrıca 2012 yılı tespitlerine göre Türkiye'de kadın belediye başkanlarının oranı \% 0.92'dir (OKA, 2012: 87). Bir detay olarak, siyaset ve ciddi kamu işleriyle ilgilenen kadınların durumlarını Kandiyoti şöyle yorumlamaktadır: Kadınların Türkiye'de kamuya girmeleri 'cinsiyetsiz' bir kimlikle, hatta erkek kimliğine bürünmeleriyle kolaylaşmaktadır (1997: 179).

Türkiye'de toplumsal cinsiyet ayrımının uluslararası vesikasını BM açıklamıştır. BM Kalkınma Programı'nın yayınladığı İnsani Gelişmişlik Endeksi'ne göre Türkiye 2011'de 92. sırada bulunurken, sağlık ve üreme sağlığ1, eğitim, parlamentoda temsil edilme gibi göstergelerle oluşturulan Toplumsal Cinsiyet Eşitsizliği Endeksi'nde 0.443 ile 187 ülke arasında 77. sıradadır. Bu endekse göre en yüksek eşitlik değerine sahip ülkeler ise Norveç, Avustralya ve Hollanda'dır (OKA, 2013: 18).

\section{Bulgular ve Tartışma}

Toplumsal cinsiyet olgusu, derinliği sabit olmamakla birlikte dünyanın pek çok ülke ve toplumunda yaşanan bir eşitsizlik sorundur. Toplumsal cinsiyete dayanarak erkek ve kadına biçilen değerler, rol ve kalıplar hiyerarşik olarak erkeğin 'üstte ve önde' bulunması suretiyle ayrıştırıcıdır. Kadın, toplumsal olarak belirlenmiş cinsiyetinden ötürü erkekten ayrı, ötede, öteki olarak tutulmaktadır. Kadınlık, erkeklik statülerinin imkân ve izin verdiği ölçüde erkek egemen kültür tarafından oluşturulmuş bir kurgudur.

Günümüz Türkiye'si, Kongar'ın deyimiyle 'toplumsal ve kültürel olarak Osmanlının mirası ile Batı uygarlığının bir bireşimidir" (2004: 15). Bu bireşimin sosyokültürel ve ideolojik eserleri, direkt ve dolaylı olarak Türk kadını ve erkeğinin, Türk toplumunun bütün yaşam alanlarına yansımıştır, yansımaktadır. Türk kadınında görülen ikili yapıların ve arada kalmışlık göstergelerinin en önemli nedenlerinden biri budur. İkinci bir gerçeklik Türkiye'de yaşanan siyasi hamlelerin, yasaya dönük iyileştirmelerin veya kadın temalı sivil gelişmelerin ciddi çoğunluğunun asılsız din içerikli desturları, erkek egemenliğini ve ataerkil gelenekleri kıramamış olduğudur. Türkiye'de toplumsal cinsiyet ayrımcılığına yaslanan kadınlık olgusu, en fazla bu kaynaklardan yüz bulmaktadır. Ortaya konan istatistikler bu 
yargıyı doğrulamaktadır.

Türk toplumda 'kadınlık' kavramına denk görülen nitelikler, eşit, bağımsız ve özgün bir bireyin özelliklerinden ziyade ilk elden dişilikle ilgili niteliklerdir. Dişiliği temsil ettiği düşünülen kadına, bunun gereği olarak öncelikle eş, anne veya ailenin bir üyesi gibi karşılıklar yakıştırılmaktadır. Türkiye'de kadın toplumsal cinsiyetinden/kadınlığından dolayı evvela ev için, ev içinde uygun görülmektedir. Ev kadını ideolojisi kadının çalışma/maddi, eğitim ve sosyal hayatını birinci dereceden olumsuz etkilemektedir. Çalışan kadınlar için durum daha farklıdır. Türkiye'de çalışan kadın, erkek çalışanlara göre daha düşük özellikteki işlerde, daha düşük oranlarla yer almaktadır. Yanı sıra ev ve çocuk işleri yükümlülüğü çalışan kadınlarda ekstradan devam etmektedir. Kadın, mesleği ne olursa olsun aynı zamanda vazgeçilmez bir ev işçisi olarak düşünülmektedir. Erkeğin bu gibi sorumluluklardan muaf, en azından yüklerinin kadınla karşılaştırıldığında yok denecek kadar hafif olduğu açıktır. Oysa ailevi ve toplumsal yaşam, nüfusça denk olan her iki cinsin aynı eşitlikte (olması gereken) bir ortaklığıdır.

Türk kadınının eğitim ve siyaset dünyasındaki varlığında erkekle arasında nitelik ve niceliksel dengesizlikler bulunmaktadır. Daha az kadın, erkeklere göre daha az okumaktadır. Gerek okuma yazma veya bir eğitim kurumundan mezun olma gibi temel göstergeler gerekse akademik kadro oranları, eğitimde kadının erkekten sonra geldiğini anlatmaktadır. Kadının siyaset kulvarındaki varlığı, daha doğrusu yokluğu ise erkekle arasındaki büyük uçurumları resmetmektedir. Türkiye'de kadınlık, siyasi işlerle ilgilenmek için bir dezavantaj gibi durmaktadır. Özellikle profesyonel, aktif ve resmi siyasette kadın kendine yer bul(a)mamaktadır.

Netice itibariyle toplumsal tarafından üretilen kadınlık, zor ve ama sunî bir yaratılış kaderi gibidir. Bu kader Türkiye'de daha zorlaşmaktadır. Türkiye'de, televizyon ekranlarından kendilerine kız çocuklarının eğitimi için halen rica edilen, onları erken evlendirmemeleri ve hatta öldürmemeleri öğütlenen ailelerin kadınları olmak zordur. Yasada ve görünürde fırsat eşitliğine sahip olan kadın, düşüncedeki katı kadınlık algısında erkekle eşit değildir. Bu, anahtar bir tespittir. Çünkü çağdaş dünyada ve Türkiye'de toplumsal cinsiyet eşitsizliğinin ve kadınlık olgusu denen ötekiliğin kilidini, sadece zihniyet değişimi anahtarı açabilecektir.

\section{Kaynakça}

Acar Savran, Gülnur (2009), Beden Emek Tarih Diyalektik

Bir Feminizm İçin (2. Bask1), Kanat Kitap, İstanbul

Altındal, Aytunç (2004) Türkiye'de Kadın, Alfa Yayınları, İstanbul

Doğdu, Süleyman (2005) Kadının Serüveni - Kadın Ve Yaratılışı, Demet Kitap, Ankara

Doğrmac1, Emel (1993) Atatürk'ten Günümüze Sosyal

Değişmede Türk Kadını, Atatürk Araştırma Merkezi, Ankara Giddens, Anthony (2012) Sosyoloji, (Çeviren: İsmail Yılmaz), Kırmızı Yayınları, İstanbul

Hepşen, Özlem (2010) Tevrat, İncil Ve Kuran-I Kerimde Kadın Bedeni, Ankara Üniversitesi Sosyal Bilimler Enstitüsü Yayımlanmamış Yüksek Lisans Tezi, Ankara

Kandiyoti, Deniz. (1997) Cariyeler Yurttaşlar Bacılar Kimlikler Ve Toplumsal Dönüşümler, (Çeviren: Aksu Bora Vd.), Metis Kadın Araştırmaları, İstanbul

Kongar, Emre (2004) 21. Yüzyılda Türkiye (35. Basım), Remzi Kitabevi, İstanbul

Michel, Andree (?) Feminizm, (Çeviren: Şirin Tekeli), ?:
İletişim Yayınları

Nirun, Nihat (1994) Sistematik Sosyoloji Yönünden Aile Ve Kültür, Atatürk Kültür, Dtyk Atatürk Kültür Merkezi Yayını Sayı: 73, Ankara

Oka (Orta Karadeniz Kalkınma Ajansı) (2012), Tr83 Bölgesi Mevcut Durum Analizi, Samsun

Oka (Orta Karadeniz Kalkınma Ajansı) (2013), Türkiye Ve Tr83 Bölgesinde Toplumsal Cinsiyet Eşitsizliği Ve Kalkınma, Samsun

Russel, Bertrand (2003), Evlilik Ve Ahlak, (Çeviren: Ender Gürol), Morpa Kültür Yayınları, İstanbul

Saim, Hikmet (2004) Kadının Gizli Dünyası (3. Basım), Arıon Yayınevi, İstanbul

Tarhan, Nevzat (2005), Kadın Psikolojisi, Nesil Yayınları, İstanbul

Tc Başbakanlık Kadın Statüsü Genel Müdürlüğü Toplumsal Cinsiyet Eşitliği Ulusal Eylem Planı. (2008), Ankara

Tüik (Türkiye İstatistik Kurumu), (2010) İstatistiklerle Kadın (2010), Ankara

Wallace, Ruth A. Ve Wolf, Alison, (2004), Çağdaş Sosyoloji Kuramları, (Çeviren: Leyla Elburuz), Punto Yayıncılık, İzmir 